\title{
Female National Type in the English Literature of the XIX Century
}

\author{
M.A.Saibnazarova ${ }^{1}$ \\ ${ }^{I}$ National University of Uzbekistan Named after Mirzo Ulug'bek, English teacher, Uzbekistan \\ Email:sainbnazarova_m@umail.uz
}

\begin{abstract}
This text consists in deciphering women's themes within the cultural and historical side, analyzing the evolution of the feminine image and therefore the position of ladies within the family and society, finding out the origins of the formation of a selected canon and vision of British ladies in British culture and literature.
\end{abstract}

Keywords: national character, English literature of the XIX century, the female image.

\section{INTRODUCTION}

Today, as at the start of the XXI century, the image of a capitalist attempt for career growth is in style. At present, ladies participate in politics, come through success in skilled activities, and gain victories within the scientific field. However, even now, on the thanks to success, ladies usually ought to subsume sexism, negative opinion, and misunderstanding on the a part of alternative representatives of the "fair sex". The problem that faced feminists at the top of the nineteenth century continues to be relevant: is it attainable to take care of trait by operating and competitor in very society acceptable men. It appears that the answer to the matter lies on the one hand within the plan of trait prevailing in society, and on the opposite, within the awareness of the ladies themselves, their disposition to defend their own opinion. during this regard, the expertise of the primary generation of ladies World Health Organization entered the age of freeing at a turning purpose in history is attention-grabbing. The affirmation of the image of the energetic purposeful "new woman" was a fancy, arguable method that passed off in a very fierce struggle with the previous, ancient concepts concerning her.

The formation of the idea of the English national character takes place in culture in the Victorian era, which is considered one of the most striking and significant eras of English history. National character the British began to be comprehended, first of all, in literature and somewhat later in literary criticism. Writers and critics themselves highlight a number of features of the English national character, which, in their opinion, determine its essence. At the end of the 20th century and at the beginning of the 21 st century, a huge number of literary, cultural and sociological studies that address complex processes of formation of English national identity, British state nationalism, the relationship between them and the role of literature and writing culture in the process. The object of our study is that the feminine pictures of Victorian European nation, the issues and therefore the peculiarity of their interpretation, we tend toll also additionally further furthermore in addition likewise moreover similarly still yet as new and weird options that we discovered that the authors embodied contrary to the established canon. The theoretical significance of the work lies within the incontrovertible fact that its results will be utilized in any finding out the influence of Victorian literature on modern literature, still as in finding out the evolution of the feminine image and its implementation in modern English literature.

\section{THEORITICAL PART}

Victorian era: historical framework and characterization. The Victorian era is sometimes known as the amount of the reign of Victoria, Queen of nice Britain and Ireland, Empress of Asian country (18371901). in line with A. A. Dolinin, a student of literature and criticism: "Victorian European nation is tied to today's England by blood ties, and if we tend to don't perceive one, we tend to risk ne'er understanding the opposite." so, it's implausibly vital to know what the Victorian era is, what's its peculiarity and what is 
its place in British history. The Victorian era is taken into account to be the age of prosperity and therefore the highest peak within the development of British history, as a result of underneath the management of nice Britain there are vast territories on all continents of the world, it produces such a large amount of merchandise that no country within the world will sustain with it, the expansion of the center category, which incorporates not solely farmers and traders, however conjointly extremely skilled workers: monks, bankers, varied lawyers, diplomats, doctors and military. However, within the decennium. Britain entered a amount of another depression. "Rotten places" are being abolished, new constituencies in industrial cities are being created, the role of the House of Commons within the political lifetime of Britain is growing, the Chartist insurrection is production. Decennary were marked by famine, the mass out-migration of Irish, the U.S. insurrection O`Brien. Therefore, the Victorian era will be divided into 3 periods: the initial (until the 1850s), 1850-1870s. and therefore the late amount (18701901).

The first amount, before the start of the decade, was rather tough. Britain faced variety of significant domestic issues when the top of the warfare. British believed that the top of the wars would open up nice opportunities for the sale of products accumulated throughout their time in Europe. However Europe was in a very state of complete ruin, and British industrial merchandise couldn't be sold-out. Associate depression erupted. Matters was aggravated by a far more than labor, because of thirty thousand those that required employment came back from the war. Protests against the "bread" laws, the Luddites, the brutal suppression of uprisings and therefore the adoption of laws that even violent measures against protesters - an image that characterizes Britain at the start of the XIX century 1850-1860 - the amount of supreme prosperity and power of nice Britain. It's now amount that is closely associated with the idea of "Victorianism". When 1848 the recession of the labor began, that was amid a amount of a brand new upsurge of the class. In 1847 A law was passed limiting the operating hours of ladies and youngsters (up to ten hours). decade became the amount of greatest prosperity of British pre-monopoly free enterprise, characterized by a rise within the financial gain of entrepreneurs thanks to colonial growth. It was throughout this era that the Victorian era extremely became a sort of golden age. Britain occupied a dominant position within the world market, in hand huge colonies that created up the fabulous wealth of British treasury, developed industrial production was established and worked cleanly. Power become the most important commercialism monopolize. The efflorescence of the class, attributing national successes to itself, has come. The newly minted bourgeois wanted to strengthen leadership not solely in politics and social science, however conjointly within the field of morality, introducing strict moral standards, which, nonetheless, were violently desecrated. Though either the aristocracy or the lots did not revere the insincere norms, nonetheless, Victorian writers were forced to reckon with them, since the bulk of the reading audience was "middle class". A two-party system was established in British political life, as results of that associate alternation of a conservative and liberal system of presidency began to require place. To win the election, each parties actively hurried "to the people", parturition down the principles of labor with voters, that are relevant to the present day. However, these successes within the group action of society did not result in a qualitative modification in the lifetime of the state. After a brief amount of confidence within the state of england, in a very bright and optimistic future, the mood of a lost equilibrium, worry for the long run, a sense of uncertainty concerning tomorrow comes into society. Despite the economic and political successes, a sense of impotence of man before of the stupendous power of the empire began to reign in society. Thus, the assured bourgeois progress of the country aroused some doubts concerning the likelihood of fixing one thing within the existing order of things. Didactic and therefore the want to reveal the vices of society were replaced by disappointments, apathy and disbelief within the risk of knowing the laws of human existence.

\section{PRACTICAL PART}

Victorian ethical

Victorian morality could be a term denoting the totality of ethical values that individuals World Health Organization lived throughout the reign of Queen of England adhered to. He particularly characterizes the final atmosphere that prevailed in Britain within the nineteenth century. Most of the ethical principles were aimed toward suppressing sex, strict adherence to a code of conduct, and were conjointly supported a robust ethics and complete intolerance towards violation of rules of conduct. The 
history of Victorian morality, in fact, does not begin with Victoria; however, it goes back to the seventeenth century, once British autocracy was overthrown, and Puritan republicans came to power. Throughout the republican regime in nice Britain, a course was chosen for all types of restrictions and therefore the termination of the free customs of the country's population (even the celebration of Christmas was banned). However, when the restoration of the autocracy, fun, freedom and freeing came back to the country. Puritanism and liberalism are contradictory trends, however it had been they that influenced British mentality most of all. The generation of Hanover preceding Victoria didn't leave the foremost pleasant mark on the ethical character of the country. Thus King of England, for instance, was called a hedonist, a seeker of pleasures and a scrapper, he left vast debts when himself. Uncle Victoria, William IV all his life was truly married to associate histrionic and had ten illegitimate kids. There were conjointly sure norms and prohibitions within the relationship between a person and a lady. The word love was taboo, rather than it they used the expression: "Can I hope" with the solution "I ought to suppose." Open sympathies were prohibited. The flirtation and flirty woman was censured, they aforesaid concerning her: "She is of simple virtue," though her whole sin was that she was natural, cheerful and did not hide her disposition. a people author Charlotte mother Yunge wrote in her diary: "It was terribly tough on behalf of me between the ages of twelve and 24. I felt thus injustice such a lot that I had to much kill myself in myself ... having closed myself, shut the simplest half in a very cold iron box and keep my very own soul in silence. " One of the signs of sympathy was thought-about permission for a young man to hold a girl's prayer book upon strolling back from worship. Thus, entreaty was public, the woman wasn't purported to be alone with a person, they consisted of chin-wagging, symbolic gestures and signs. a lady was thought-about compromised if she was concisely left alone with a person World Health Organization didn't have official and heavy intentions on her.

Female status

Women did, though, require a new kind of education to prepare them for this role of 'Angel in the House'. Rather than attracting a husband through their domestic abilities, middle-class girls were coached in what were known as 'accomplishments'. These would be learned either at boarding school or from a resident governess. In Jane Austen's Pride \& Prejudice the snobbish Caroline Bingley lists the skills required by any young lady who considers herself accomplished:

A woman must have a thorough knowledge of music, singing, drawing, dancing, and the modern languages ... ; and besides all this, she must possess a certain something in her air and manner of walking, the tone of her voice, her address and expressions(ch. 8)

As Miss Bingley emphasizes, it was important for a well-educated girl to soften her erudition with a graceful and feminine manner. No one wanted to be called a 'blue-stocking', the name given to women who had devoted themselves too enthusiastically to intellectual pursuits. Bluestockings were considered unfeminine and off-putting in the way that they attempted to usurp men's 'natural' intellectual superiority. Some doctors reported that too much study actually had a damaging effect on the ovaries, turning attractive young women into dried-up prunes. Later in the century, when Oxford and Cambridge opened their doors to women, many families refused to let their clever daughters attend for fear that they would make themselves unmarriageable.

\section{The position of ladies within the Victorian era}

The position of a lady in Victorian European nation wasn't the foremost desirable. in line with the law, she wasn't thought-about individually from her husband, moreover, her entire condition was thoughtabout, when wedding, to be the state of her husband. during this case, the lady couldn't inherit something. a lady had to form any money choices solely with the consent of her husband, if she required to figure so as to measure, then for a lady of social class and higher than, there was a restricted vary of professions (governess or companion). Since the birth of women, they need been educated to adjust the desire of her husband, to endure all his shortcomings (drunkenness, profligacy, addiction to gambling, ruination the family). The mothers or governesses were engaged in raising the women, and therefore the fathers raised the sons.

Divorce was conjointly a sensitive issue. In general, British women were thought-about wrongfully inferior voters of the country: their rights to inheritance and possession of property were restricted, divorce was nearly not possible. The divorce procedure provided several edges to men, and over two hundred years, Parliament approved solely four lawsuits by residents of the United Kingdom. it 
had been nearly not possible to urge him, and when him the lady would be expelled from a good society. Until 1857, divorce in European nation was associate implausibly advanced and costly procedure and concerned many stages. At first, the spouses World Health Organization needed to urge a divorce filed associate application for separation with the church court, and then the husband may leave the house. However, separation was not thought-about a divorce, because of formally the person and girl were still married, and so could not unite or wed. Once separated, the husband was conjointly obligated to pay the woman an annual allowance.

Treason was the foremost in style reason for divorce, however faraway from invariably succeeding in obtaining a divorce for this reason. If the betrayal occurred on the part of the woman, then it had been enough for the person to seek out 2 witnesses and pay the legal prices. Within the case of the male fornication, the very fact of treason was not enough; intensifying circumstances, for instance, incest, were required.

The head of the family has invariably been a person. The destiny of the woman was to make comfortableness and an environment of comfort and heat within the house so the person needed to come there. Ladies had to figure loads, although they had domestic servants. laundry windows, getting ready vegetables and fruits, stitching curtains and garments for worshipped ones - all this had to be done by several Victorians, however none of them may say concerning their fatigue and work, as this may have born it within the eyes of society.

Female image in English literature. The "home angel" from real-life passed into the literary. Within the works written by men, the idealization of the feminine image was created. Among the heroes of C. Dickens, one will realize several canonical virtuous and passive women from completely different social categories (Florence Dombey, Agness, Rose Maily). Some authors additional an explicit peculiarity to their heroines so as to save lots of them from stereotyping, for instance, feminine pictures of T. Hardy, W. author are a selected embodiment of hunters for grooms and positive virtuous heroines. But still, the plot when ends with the appreciated of virtue and therefore the penalty of vice.

Many books of this era show pictures of a perfect girl World Health Organization, whenever she thought that her husband is inattentive to her and spends all her free time in a very club or elsewhere, doesn't take offense, however instead, takes a deep breath and drives away the incorrect thoughts, thinks: "My main task is to form everybody within the house happy!"

In the literature, a new type of woman appears. Victorian ideal. In the work of T. Hardy appears the image of a strong and a born woman with a tragic fate that resemble dicken Soviet heroines are only situational, but not conceptual. The level of the level of irony in the depiction of female images, this applies even to the image of non- gray old virgin. The image of Marion Golcombe in the novel by W. Collins less ", it's more like an image of a smart woman, whose virtues are not able to assess thread English men by virtue of their limitations. New are female images of Bernard Shaw, illustrating his theory of vitality, a leading force in the world, the bearer of which is a woman. Heroines of it plays are independent and not dependent on men, insolvent in all respects relations. The ideals of "lady" and "gentleman", by contrast, become the subject of avionic irony. So, the heroines of the play "Mrs. Warren's Profession" from the very beginning The beginnings of the play are contrasted with the image of the "lady," but not only Vivi, the image a bathroom and a self-contained girl, but also Mrs. Warren herself, each in her own I mean non-ladies are more attractive than parody types "Gentleman" (Pred) and "pseudo-gentleman" (Crofts, Fred Gardner) characters. Mimicking the very idea of "lady" and "gentleman" becomes the basis of the Pygmalion's most popular play, in which Eliza's triumph Dullittle and Higgins' embarrassment stresses the failure of national stereotypes of social behavior.

\section{CONCLUSION}

Thus, in the literature of the XIX century in the process of self-identification an idea of the features of an English national character is emerging. The ideal of social behavior (lady) is gradually transformed into a model national behavior in parallel with the blurring of social boundaries3, evidence of which is the breaking of the obligatory connection of the noble the origin and adherence to the "lady" code of conduct. In parallel, based on social stereotype, a stereotype of national behavior is formed, distinguishing the Englishwoman from the representatives of other nations. 


\section{REFERENCES}

1. Austen, J. Pride and Prejudice [Text] / J. Austen / Transl. by I.S. Marshak. Perm, 1993. -512 p.

2. Gerivas, D. Literary Englands. Versions of «Englishness» in Modern Writing D. Gerivas.Cambridge: Cambridge University Press, 1993. -512 p.

3. Gicandi, S. Maps of Englishness. Writing, Identity in the Culture of Colonialism, S. Gicandi. NY: Columbia University Press, 1996. - 268 p.

4. Hewitt, K. Understanding English Literature [Text] / K.Hewitt. - Oxford: Perspective Publications, 1997. $-280 \mathrm{p}$.

5. Langford, P. Englishness Identified. Manners and Character 1650-1850 P. Langford. - Oxford: Oxford University Press, 2000. - $435 \mathrm{p}$.

6. Orwell, G. Englishmen G.Orwell // G. Orwell "1984" and Essays of Various

7. Years. - Moscow: Progress, 1989. -377 p.

8. https://www.bl.uk/romantics-and-victorians/articles/gender-roles-in-the-19th-century 